\title{
Paradoxical Pupil Reaction due to Acetylcholine and Nicotine after Splanchnicotomy or Medullisuprarenalectomy.
}

\author{
By \\ Syugo Kojima. \\ (小島修珸) \\ (From the Physiological Laboratory of Prof. Y. Satake, \\ Tohoku Imperial University, Sendai.)
}

As acetylcholine $\mathrm{e}^{1)}$ and nicotine $\mathrm{e}^{2)}$ accelerate the epinephrine secretion from the suprarenals by acting upon their medulla, how cutting the splanchnic nerves or removing the suprarenal medulla influences the occurrence of the paradoxical pupil reaction on applying both drugs subcutaneously or intravenously is a problem of highly interesting. Not only there are no comparative studies with both drugs in respect to this question, but the results of experiments of such a design by the previous writers dealing with each drug are also so discordant with each other, that it is almost impossible to aware of truth. ${ }^{3) 4}$ )

In the present investigations parallel determinations with both drugs were carried out of the pupil width, sensitized by removing the ipsilateral upper cervical sympathetic ganglion, of cats, before and after double splanchnicotomy or double medullisuprarenalectomy. There are now striking differences in the magnitude of reactions between both drugs, as given in the following paragraphs, splanchnicotomy or medulli-suprarenalectomy.

\section{Methods.}

Seven cats were used for the control, eight after splanchnicotomy and three after demedullation of suprarenals.

The superior cervical ganglion was removed aseptically under ether narcosis. The sensitiveness of the denervated pupil to adrenaline is most large at about the sixth to tenth day after the removal of the 
superior cervical ganglion, according to a systematic study ${ }^{5}$. So the experiments were carried out in the second week after the ganglionectomy. The pupil width was measured before and after administration of the drugs.

For doing so the cat was put into a bag with the head kept therefrom. Sometimes the nictitating membrane was withdrawn by means of a small clip, if necessarily. Some attention was paid to behaviour of the nictitating membrane and the right pupil.

For injection an external jugular vein was prepared; it was laid bare under local anaesthesia with 0.5 per cent novocain solution, then a glass cannula with a rubber tube, ligated at the opposite end, was inserted into the central end of vein. No injection was done when pupil width fluctuated. The volume of fluid for injection was made to 1 c.c. by adding physiological saline solution, and it was injected in 4-9 seconds.

The minimum effective dose for eliciting the paradoxical pupil dilatation was searched for by repeating injections of the drug solution of various amounts, with some regular interval, 5 minutes or more in cases of acetylcholine and 10 minutes or longer in those of nicotine.

Acetylcholine (acetylcholine chloratum, Shering-Kahlbaum) was used in $0.01,0.001$ and 0.0001 per cent solution, and nicotine (nicotine puris, Merck) in 0.01 and 0.001 per cent solution.

Splanchnic nerves and suprarenals were approached by the lumbar way under ether anaesthesia. Splanchnic nerves were cut out in a length of $1 \mathrm{~cm}$. under diaphragma, and the gland was deprived of the medullary tissue in the manner described elsewhere. ${ }^{6)}$

In the left gland of Cat $\mathrm{M} 3$ a very small portion of medulary tissue was found on histological examination post mortem. It was very small and the results in that cat are not different from the remainings.

\section{Results.}

For showing the routine course of experimentation a single example is given here, and all the data are summarized in tabular form.

With small doses, such as to cause just the paradoxical pupil dilatation or a little greater, cats showed sometimes no abnormities, sometimes some weak symptoms, nystagmus, deepened respiration. Slight exophthalmus, tearfulness, quickened breathing took place seldom. Cats became sometimes restless. They lasted only for a short time, such as some ten seconds. Nystagmus occurred more frequently on nicotine than on acetylcholine. 


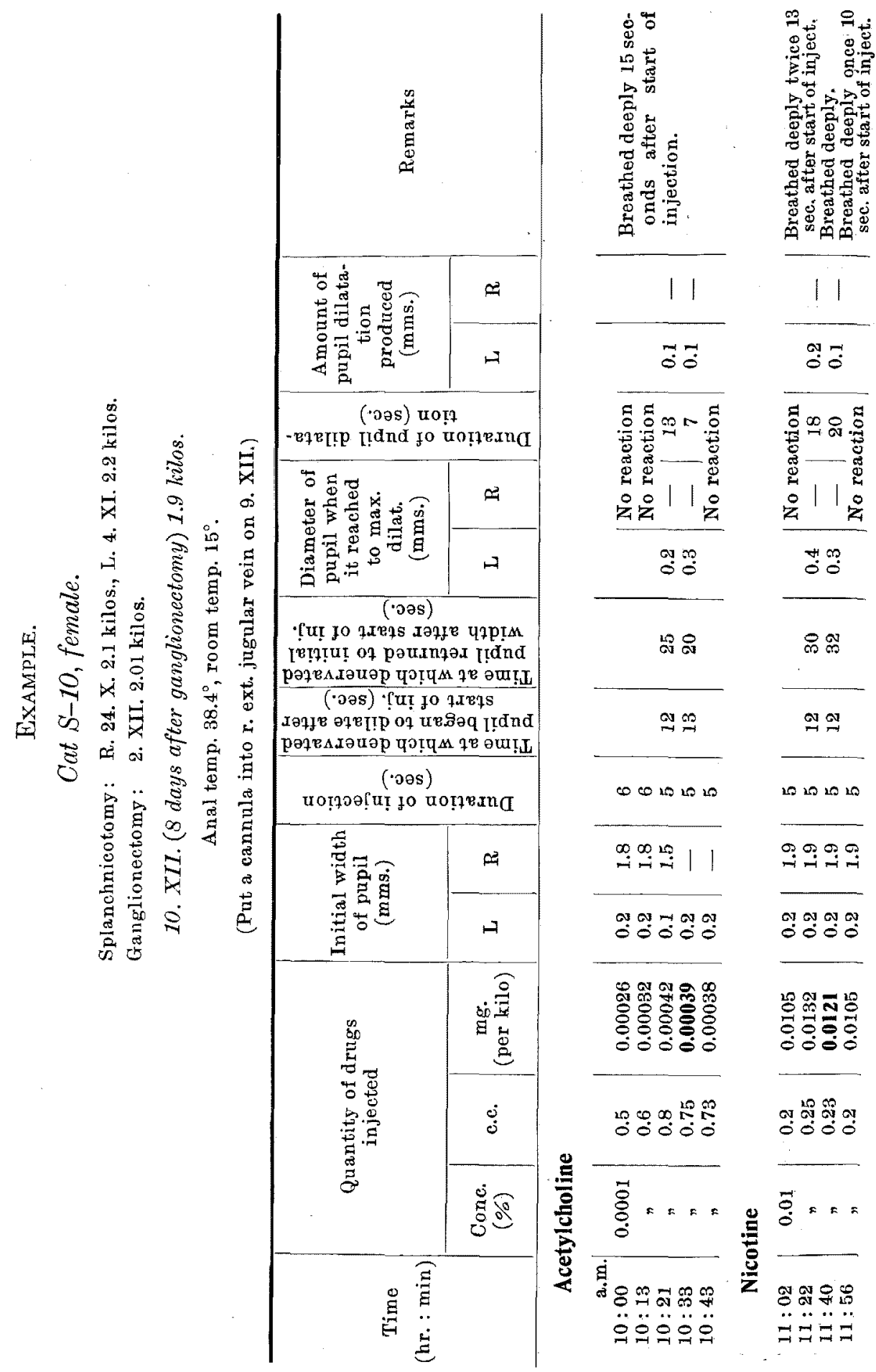




\section{TABLE I.}

Presenting the paradoxical pupil reaction caused by acetylcholine in the cats with intact, denervated and demedullated supurarenals.

(Body weight is presented in italic.)

\begin{tabular}{|c|c|c|c|c|c|c|c|c|c|c|}
\hline \multirow{3}{*}{$\begin{array}{c}\text { No. and } \\
\text { sex of } \\
\text { cat }\end{array}$} & \multicolumn{3}{|c|}{$\begin{array}{l}\text { Date of operation } \\
(1937-38)\end{array}$} & \multirow{2}{*}{\multicolumn{7}{|c|}{$\begin{array}{l}\text { Minimal dose which produced the paradoxical pupil } \\
\text { reaction on the following days after removal of the } \\
\text { superior cervical ganglion (ngrm. per kilo of body } \\
\text { weight) }\end{array}$}} \\
\hline & \multicolumn{2}{|c|}{$\begin{array}{l}\text { Splanchni- } \\
\text { cotomy or } \\
\text { demedul- } \\
\text { lation }\end{array}$} & \multirow{2}{*}{ 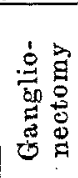 } & & & & & & & \\
\hline & $\mathbf{R}$ & $\mathbf{L}$ & & 7 & 8 & 9 & 10 & 11 & 12 & 13 \\
\hline
\end{tabular}

\section{Normal cats}

\begin{tabular}{|c|c|c|c|c|c|c|c|c|}
\hline$N-6 \quad \widehat{\jmath}$ & 今 & $\mid \begin{array}{c}20.1 \mathrm{XX} \\
(1.6)\end{array}$ & $\left\{\begin{array}{l}0.00096 \\
(1.55)\end{array}\right.$ & $\begin{array}{c}0.00062 \\
(1.52)\end{array}$ & & & & $\begin{array}{l}0.0013 \\
(1.49)\end{array}$ \\
\hline$N-7$ & $\delta$ & $\begin{array}{l}11 . \mathrm{X} \\
(2.25)\end{array}$ & $\mid \begin{array}{r}0.0010 \\
(2.02)\end{array}$ & & $\begin{array}{r}0.0008 \\
(1.87)\end{array}$ & $\begin{array}{r}0.0011 \\
(1.92)\end{array}$ & $\begin{array}{c}0.00108 \\
(1.9)\end{array}$ & \\
\hline $\mathrm{N}-8$ & $\hat{\delta}$ & $\mid \begin{array}{c}1 . \mathrm{XI} \\
(2.1)\end{array}$ & $\left(\begin{array}{r}0.0009 \\
(2.11)\end{array}\right.$ & $\begin{array}{c}0.0007 \mathrm{I} \\
(2.11)\end{array}$ & $\begin{array}{l}0.0005 \\
(2.01)\end{array}$ & & $\begin{array}{c}0.00105 \\
(1.92)\end{array}$ & \\
\hline N-9 & $\delta$ & $\left.\begin{array}{r}19 . \mathrm{XI} \\
(1.64)\end{array}\right)$ & $\begin{array}{c}0.00094 \\
(1.58)\end{array}$ & $\mid \begin{array}{c}0.00087 \\
(1.52)\end{array}$ & $\begin{array}{c}0.00138 \\
(1.44)\end{array}$ & & & \\
\hline $\mathrm{N}-10$ & ธิ & $\mid \begin{array}{l}2 . \mathrm{XII} \\
(2.2)\end{array}$ & $\begin{array}{c}0.00077 \\
(2.18)\end{array}$ & $\mid \begin{array}{c}0.00065 \\
(2.01)\end{array}$ & $\begin{array}{r}0.0004 \\
(1.99)\end{array}$ & & & \\
\hline $\mathrm{N}-11$ 우 & 우 & $\begin{array}{c}6 . \mathrm{XII} \\
(2.1)\end{array}$ & $\begin{array}{c}0.00095 \\
(1.88)\end{array}$ & $\begin{array}{c}0.00021 \\
(1.82)\end{array}$ & {$\left[\begin{array}{c}0.00023 \\
(1.77)\end{array}\right.$} & & & \\
\hline $\mathrm{N}-12$ & 우 & 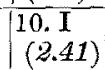 & $\mid \begin{array}{c}0.00174 \\
(2.26)\end{array}$ & $\begin{array}{c}0.00158 \\
(2.37)\end{array}$ & $\begin{array}{c}0.00125 \\
(2.43)\end{array}$ & $\begin{array}{l}0.0008 \\
(2.47)\end{array}$ & $\begin{array}{r}0.0010 \\
(2.46)\end{array}$ & \\
\hline$\overline{\text { Average }}$ & & & 0.00104 & 0.00074 & $\mid 0.00076$ & 0.00095 & 0.00106 & 0.0013 \\
\hline
\end{tabular}

Splanehnicotomized cats

\begin{tabular}{|c|c|c|c|c|c|c|c|c|c|c|c|}
\hline$S-5$ & 우 & $\begin{array}{l}5 . \mathrm{VI} \\
(1.86) \\
\end{array}$ & {$\left[\begin{array}{l}21 . \mathrm{VIT} \\
(2.16)\end{array}\right.$} & $\left\{\begin{array}{c}20.1 X \\
(2.3)\end{array}\right.$ & $\mid \begin{array}{c}0.00065 \\
(2.27)\end{array}$ & $\begin{array}{c}0.00068 \\
(2.2)\end{array}$ & $\begin{array}{c}0.00087 \\
(2.28)\end{array}$ & & $\begin{array}{c}0.00091 \\
(2.2)\end{array}$ & & \\
\hline $8-6$ & $\delta$ & $\begin{array}{l}7 . \mathrm{VI} \\
(2.2)\end{array}$ & $\begin{array}{l}21 . \overline{V I I} \\
(1.8)\end{array}$ & $\begin{array}{l}7 . \mathrm{X} \\
(2.18)\end{array}$ & $\left|\begin{array}{c}0.00043 \\
(2.3)\end{array}\right|$ & $\left|\begin{array}{c}0.00065 \\
(2.27)\end{array}\right|$ & {$\left[\begin{array}{c}0.00068 \\
(2.23)\end{array}\right.$} & $\begin{array}{l}0.00091 \\
(2.2)\end{array}$ & & & \\
\hline S-7 & 우 & $\begin{array}{c}1 . \mathrm{X} \\
(2.47)\end{array}$ & $\mid \begin{array}{c}24 . \mathrm{x} \\
(2.52)\end{array}$ & $\begin{array}{l}8 . \mathrm{XI} \\
(2.6)\end{array}$ & $\begin{array}{r}0.0005 \\
(2.64)\end{array}$ & $\begin{array}{c}0.00037 \\
(2.69)\end{array}$ & $\begin{array}{c}0.00019 \\
(2.64)\end{array}$ & $\begin{array}{c}0.00027 \\
(2.6)\end{array}$ & {$\left[\begin{array}{c}0.00031 \\
(2.61)\end{array}\right.$} & & \\
\hline S-9 & 우 & $\begin{array}{c}24 . \mathrm{X} \\
(2.15)\end{array}$ & $\left(\begin{array}{c}4 . \mathrm{XI} \\
(2.06)\end{array}\right)$ & $\left\{\begin{array}{l}22 . \mathrm{XI} \\
(2.6)\end{array}\right.$ & $\mid \begin{array}{c}0.00015 \\
(2.57)\end{array}$ & $\begin{array}{r}0.0002 \\
(2.54)\end{array}$ & $\begin{array}{c}0.00012 \\
(2.5)\end{array}$ & $\begin{array}{c}0.00015 \\
(2.49)\end{array}$ & $\begin{array}{r}0.0002 \\
(2.58)\end{array}$ & $\begin{array}{c}0.0002 \\
(2.56)\end{array}$ & $\begin{array}{c}0.00019 \\
(2.45)\end{array}$ \\
\hline S-10 & 우 & $\begin{array}{l}24 . \mathrm{X} \\
(2.1)\end{array}$ & $\begin{array}{l}4 . \mathrm{XI} \\
(2.2)\end{array}$ & $\begin{array}{c}2 . \mathrm{XII} \\
(2.01)\end{array}$ & $\left|\begin{array}{c}0.00034 \\
(1.9)\end{array}\right|$ & $\begin{array}{c}0.00039 \\
(1.9)\end{array}$ & $\begin{array}{c}0.00037 \\
(1.84)\end{array}$ & & $\left(\begin{array}{c}0.0005 \\
\left(1.97^{\prime}\right)\end{array}\right.$ & {$\left[\begin{array}{c}0.00083 \\
(2.06)\end{array}\right]$} & $\begin{array}{c}0.00105 \\
(1.95)\end{array}$ \\
\hline$S-12$ & 우 & $\begin{array}{r}21 . \mathrm{XI} \\
(3.16)\end{array}$ & $\left|\begin{array}{c}3 . \mathrm{XII} \\
(3.1)\end{array}\right|$ & $\begin{array}{l}16 . \mathrm{XII} \\
(3.15)\end{array}$ & {$\left[\begin{array}{c}0.00039 \\
(3.12)\end{array}\right.$} & $\begin{array}{c}0.00041 \\
(3.18)\end{array}$ & $\begin{array}{c}0.00039 \\
(3.11)\end{array}$ & $\begin{array}{l}0.00039 \\
(3.1)\end{array}$ & $\begin{array}{r}0.0003 \\
(3.15)\end{array}$ & $\begin{array}{c}0.00038 \\
(3.18)\end{array}$ & $\begin{array}{c}0.00022 \\
(3.12)\end{array}$ \\
\hline S-13 & $\delta$ & & $\begin{array}{l}\mathrm{XI} \\
.37)\end{array}$ & $\begin{array}{l}\text { 16. XII } \\
(2.5)\end{array}$ & $\begin{array}{l}0.00028 \\
(2.49)\end{array}$ & $\begin{array}{c}0.00057 \\
(2.85)\end{array}$ & $\begin{array}{r}0.00048 \\
(2.52)\end{array}$ & & $\begin{array}{c}0.0006 \\
(2.5)\end{array}$ & $\begin{array}{c}0.00083 \\
(2.44)\end{array}$ & $\begin{array}{c}0.0092 \\
(2.5)\end{array}$ \\
\hline$S-15$ & 今ิ & & $\begin{array}{l}\text { VII } \\
.45)\end{array}$ & $\begin{array}{l}\text { 1.VIII } \\
(2.2)\end{array}$ & $\begin{array}{c}0.00043 \\
(2.3)\end{array}$ & & $\begin{array}{c}0.00055 \\
(2.2)\end{array}$ & $\begin{array}{r}0.00053 \\
(2.22)\end{array}$ & & & \\
\hline Avera & & & & & 0.0004 & 0.00046 & 0.00045 & $0 . \overline{00045}$ & 0.00046 & 0.00056 & 0.0006 \\
\hline
\end{tabular}

Medulli-suprarenalectomized cats

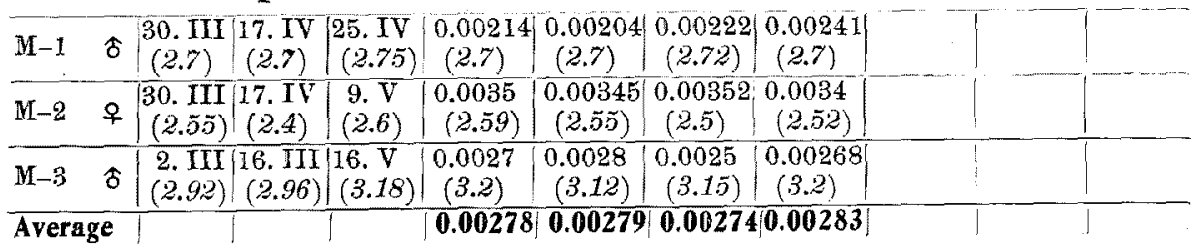




\section{TABLe II.}

Presenting the paradoxial pupil reaction caused by nicotine in the cats with intact, denervated and demedullated suprarenals.

(Body weight is presented in italic.)

\begin{tabular}{|c|c|c|c|c|c|c|c|c|c|c|}
\hline \multirow{3}{*}{$\begin{array}{c}\text { No. and } \\
\text { sex of } \\
\text { cat }\end{array}$} & \multicolumn{3}{|c|}{$\begin{array}{c}\text { Date of operation } \\
(1937-38)\end{array}$} & \multirow{2}{*}{\multicolumn{7}{|c|}{$\begin{array}{l}\text { Minimal dose which produced the paradoxical pupil } \\
\text { reaction on the following days after removal of the } \\
\text { superior cervical ganglion (mgrm. per kilo of body } \\
\text { weight) }\end{array}$}} \\
\hline & \multicolumn{2}{|c|}{$\begin{array}{l}\text { Splanchni- } \\
\text { cotomy or } \\
\text { demedul- } \\
\text { lation }\end{array}$} & \multirow{2}{*}{ 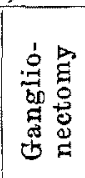 } & & & & & & & \\
\hline & $\mathbf{R}$ & $\mathbf{L}$ & & 7 & 8 & 9 & 10 & 11 & 12 & 13 \\
\hline
\end{tabular}

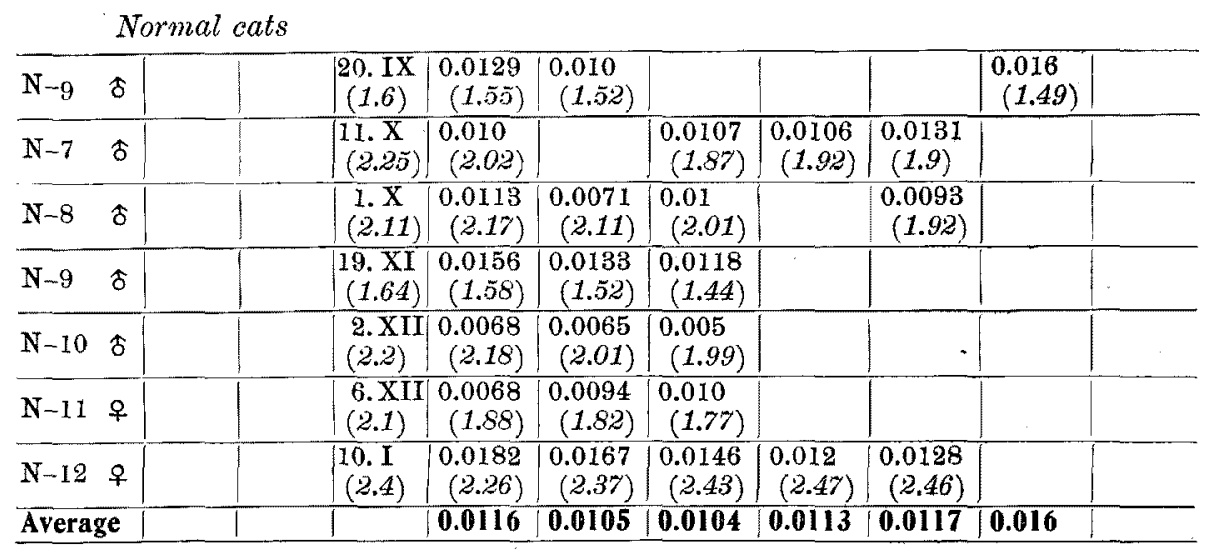

Splanchnicotomized cats

\begin{tabular}{|c|c|c|c|c|c|c|c|c|c|c|c|}
\hline$S-5$ & 우 & $\begin{array}{r}5 . \mathrm{VIT} \\
(1.86)\end{array}$ & {$\left[\begin{array}{l}21 . \mathrm{VII} \\
(2.16)\end{array}\right.$} & $\left\{\begin{array}{l}20 . \mathrm{IX} \\
(2.3)\end{array}\right.$ & $\begin{array}{c}0.0131 \\
(2.27)\end{array}$ & $\begin{array}{c}0.0099 \\
(2.2)\end{array}$ & $\begin{array}{r}0.0065 \\
(2.28) \\
\end{array}$ & & $\begin{array}{l}0.0091 \\
(2.2)\end{array}$ & & \\
\hline S-6 & $\delta$ & $\begin{array}{c}7 . \text { VIT } \\
(2.2)\end{array}$ & $\begin{array}{l}21 . \text { VII } \\
(1.8)\end{array}$ & $\left|\begin{array}{c}7 . \mathrm{X} \\
(2.18)\end{array}\right|$ & $\begin{array}{c}0.0087 \\
(2.3)\end{array}$ & $\begin{array}{r}0.0087 \\
(2.27)\end{array}$ & $\begin{array}{r}0.0068 \\
(2.23)\end{array}$ & $\begin{array}{c}0.0068 \\
(2.2)\end{array}$ & & & \\
\hline$S-7$ & 오 & $\begin{array}{c}1 . \mathrm{X} \\
(2.47)\end{array}$ & $\left\{\begin{array}{l}24 . \bar{X} \\
(2.52)\end{array}\right.$ & $\begin{array}{c}8 . \mathrm{XI} \\
(2.6)\end{array}$ & $\begin{array}{c}0.0095 \\
(2.64)\end{array}$ & $\begin{array}{l}0.0074 \\
(2.69)\end{array}$ & $\begin{array}{r}0.0078 \\
(2.64)\end{array}$ & $\begin{array}{c}0.0095 \\
(2.6)\end{array}$ & $\begin{array}{r}0.0115 \\
(2.61)\end{array}$ & & \\
\hline S-9 & 우 & $\left|\begin{array}{c}24 . \mathrm{X} \\
(2.15)\end{array}\right|$ & $\begin{array}{c}4 . \mathrm{XI} \\
(2.06)\end{array}$ & $\begin{array}{l}22 . \mathrm{XI} \\
(2.6)\end{array}$ & $\begin{array}{r}0.0173 \\
(2.57)\end{array}$ & $\begin{array}{r}0.0140 \\
(2.54)\end{array}$ & $\begin{array}{c}0.0122 \\
(2.5)\end{array}$ & $\begin{array}{r}0.0140 \\
(2.49)\end{array}$ & $\begin{array}{r}0.0146 \\
(2.58)\end{array}$ & & \\
\hline S-10 & 우 & $\left|\begin{array}{c}24 . \mathrm{X} \\
(2.1)\end{array}\right|$ & $\begin{array}{c}4 . \mathrm{XI} \\
(2.2)\end{array}$ & $\left|\begin{array}{c}2 . \mathrm{XII} \\
(2.01)\end{array}\right|$ & $\begin{array}{c}0.0121 \\
(1.9)\end{array}$ & $\begin{array}{c}0.0121 \\
(1.9)\end{array}$ & $\begin{array}{c}0.0122 \\
(1.84)\end{array}$ & & $\begin{array}{c}0.0150 \\
(1.97)\end{array}$ & & \\
\hline $\mathrm{S}-12$ & 우 & $\left|\begin{array}{c}21 . \mathrm{XI} \\
(3.16)\end{array}\right|$ & $\begin{array}{l}\text { 3. XII } \\
(3.1)\end{array}$ & {$\left[\begin{array}{c}16 . \mathrm{XII} \\
(3.16)\end{array}\right.$} & $\begin{array}{r}0.0129 \\
(3.12)\end{array}$ & $\begin{array}{r}0.0109 \\
(3.18)\end{array}$ & $\begin{array}{r}0.0097 \\
(3.11)\end{array}$ & $\begin{array}{r}0.009 \\
(3.1)\end{array}$ & $\begin{array}{r}0.0104 \\
(3.15)\end{array}$ & $\begin{array}{r}0.0125 \\
(3.18)\end{array}$ & \\
\hline S-13 & $\delta$ & $\begin{array}{r}27 . \\
\\
\end{array}$ & & {$\left[\begin{array}{l}16 . \mathrm{XII} \\
(2.5)\end{array}\right.$} & $\begin{array}{l}0.0108 \\
(2.49)\end{array}$ & $\begin{array}{c}0.0096 \\
(2.85)\end{array}$ & $\begin{array}{r}0.0092 \\
(2.52)\end{array}$ & & $\begin{array}{c}0.0132 \\
(2.5)\end{array}$ & & \\
\hline$S-15$ & 令 & & & $\begin{array}{l}1 . \mathrm{VIII} \\
(2.2)\end{array}$ & $\begin{array}{c}0.0087 \\
(2.3)\end{array}$ & & $\begin{array}{c}0.0104 \\
(2.2)\end{array}$ & $\begin{array}{r}0.0099 \\
(2.22)\end{array}$ & & & \\
\hline Avera & & & & & 0.0116 & 0.0104 & 0.0094 & 0.0098 & 0.0123 & 0.0159 & 0.0153 \\
\hline
\end{tabular}

Medulli-suprarenalectomized cats

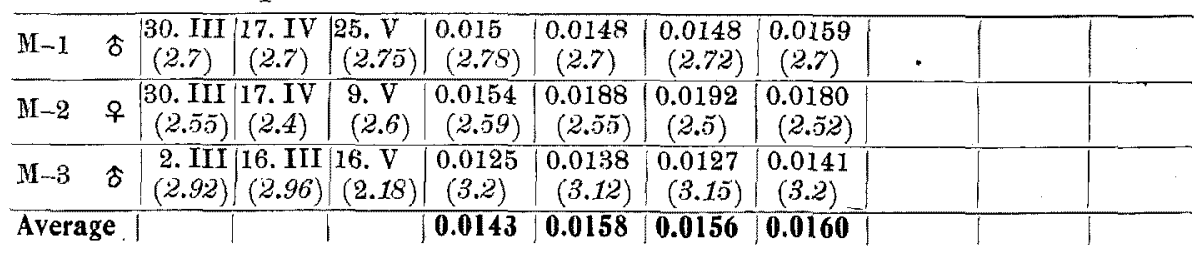


(1) Minimum effective dose of acetylcholine and nicotine for producing paradoxical pupil reaction in normal cats, not narcotized, not fastened.

All the experiments were first carried out when 7 days elapsed after the ganglionectomy. When experimented on normal individuals, the minimal doses of both drugs were found most small 8 and 9 days after the ganglionectomy; intravenous dose was $0.00076 \mathrm{mg}$. per kilo for ACh and $0.0104 \mathrm{mg}$. for nicotine. That of nicotine was as large as about fifty times of ACh.

It is very striking to find very different figures rê the ratio of the effective doses of both drugs in some similar kinds of researches.

The ratio of the minimum effective dose of acetylcholine: nicotine is about 100:1 in Houssay and Molinelli ${ }^{7}$, 1:5 in Feldberg, Minz and Tsudzimura ${ }^{8}$, about 15 (subc.): 1 (i.v.) in Inaba and Watanabe ${ }^{10)}$, and 3-5:1 (i.v.) in Wad $a^{11\rangle 12\rangle}$. All the workers measured influence of both drugs upon the epinephrine output rate while the present work deals with the paradoxical pupil dilatation, and the ratio is $1: 15$.

H. \& M. and I. \& W. experimented on dogs; while the former narcotized them with chloralose, no narcosis was resorted to by the latter. F., M. \& T. used cats under chloralose. H. \& M. injected the drugs into the suprarenal gland itself, F., M. \& T. into a. coeliaca, and I. \& W. intravenously. H. \& M. recorded the arterial pressure in the donor, whose heart was denervated, F., M. \& T. recorded the arterial pressure, and I. \& W. and W. collected blood from the suprarenal gland which was exposed by the lumbar approach without narcotizing or fastening, and determined epinephrine therein by means of the rabbit intestine strip. The experiments of In a b a and W a ta n ab e were carried out by them, one as a chief operater, another as an assistant with some other assistants. The figures in four papers (I., W., W.) do not indicate the minimum effective quantity, but they are to be approximately comparable each other. It is rather astonishing that the ratio from their data is quite opposite to the present viz. $3-5: 1$ against $1: 15$. What is responsible for such a rather qualitative or fundamental difference?

Be the above quotations only taken into account, the ratio differs according to species of animals, viz. cats and dogs. For cats. 1:5 of Feldberg et al., who measured epinephrine output and $1: 15$ in the present research, dealt with the paradox, and for dogs: 100:1 in Houssay et al., 15 (subc.): 1 (i.v.) in In aba and Watanabe, and 3-5: 1 (both i.v.) in Wada, who all studied of epinephrine liberation. 
We wished to find previous papers reporting something like the minimum i.v. effective dose of the drugs for bringing about epinephrine discharge from the suprarenals in cats, but not by means of the denervated pupil, almost in vain. $0.025 \mathrm{mg}$. nicotine per kilo might be taken as approximately corresponding to it (it was injected at once, while drug solutions in the present experiments were introduced from to time with a regular interval), not so differ from the present outcome dealt with the paradoxical pupil reaction $(0.01 \mathrm{mg}$. per kilo). It is the figure obtained from the cats under ether, whose suprarenal blood was collected by means of the cava pocket. ${ }^{13)}$ There are a great number of experiments of $\mathrm{Feldberg}$ and co-workers, who investigated action of $\dot{\mathrm{ACh}}$ on epinephrine secretion, but the drug was injected into the coeliac artery, but not intravenously.

\section{(2) After double splanchnicotomy.}

About two weeks to three months were allowed to elapse after the last splanchnicotomy to "paradox" experiment.

The both sides operation were carried out about two weeks apart. In two cats (S-13 \& S-15) it was done at once.

Splanchnicotomy lessened distinctly the minimum i.v. effective dose of $\mathrm{ACh}$ for causing the paradox. In the average it was 0.0004 $0.0005 \mathrm{mg}$. per kilo of body weight, roughly speaking about as half as large of that for normal cats: Reference Table I.

Contrary to ACh the minimum i.v. effective dose of nicotine was not altered, if any, by double splanchnicotomy, as clearly shown in a further abridged figure too.

If ample length of time be allowed to elapse after denervation of an organ or a tissue, it will become hypersensitive, as well known, to adrenaline, pilocarpine, etc. Similar evidences have been recently accumulated for acetylcholine on epinephrine secretion ${ }^{14 ; 20)}$, carbohydrate metabolism $^{14)}$, skelett muscle ${ }^{15)}$, pupillary sphincter ${ }^{16)}$, sympathetic ganglion ${ }^{19)}$, salivary ${ }^{22)}$ and lacrimal secretion. ${ }^{23)}$

In the experiments of $\mathrm{W}$ ad a who was not able to find hypersensitiveness of the suprarenal medulla to ACh, the splanchnic nerves were cut acutely only. In a further experiments, which are not yet published, Wad a gave ACh some days after splanchnicotomy with quite same the results (Personal communication. November'41.Y.S.). Of this problem we shall have another occasion to report in detail.

It is regrettable that we have not yet an opportunity to know experimental data of $\mathrm{M}$ oris on and $\mathrm{Ach}$ eso $\mathrm{D}^{21}$, which should have just some bearing upon the question at issue.

As above concluded, it is general figure that double splanchnicotomy, if some ample time be allowed to elapse thereafter, acts to exaggerate the paradoxical pupil dilatation on intravenous administration of $\mathrm{ACh}$; this is based on 


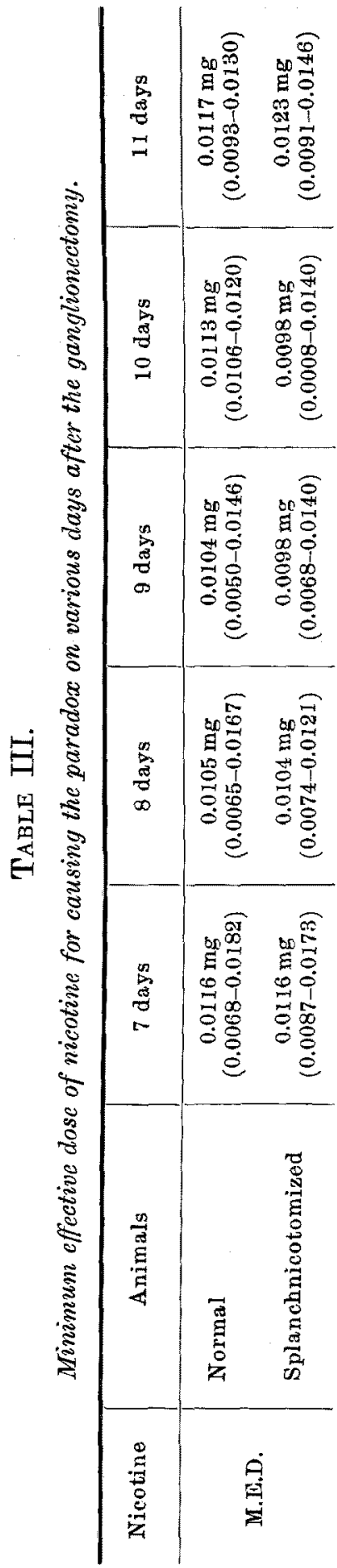

a somewhat large number of experiments. If each case to be considered on, there are some exceptional cases; the figures of Cat N-11 8 days and 9 days after ganglionectomy are, for examples, incomparatively small, and those of Cat S-5 9 days and 11 days after ganglionectomy are incomparatively large. Exceptional cases are however small compared to the salivary secretion experiment of Simeone and $\mathrm{Maes}^{22)}$, for instances. While testing epinephrine secretion from the suprarenal capsule, partially denervated, the paradoxical pupil being taken as the indicator, Simeone also had some exceptional instances, probably in one third of cats. ${ }^{20)}$

Although there are some previous experiments showing increase in epinephrine discharge due to nicotine still after splanchnicotomy, only a few are available for quantitative study. It is so far beyond doubt that splanchnicotomy, done either acutely or long time before, does not act at least to exaggerate the hypersecretion of epinephrine from the suprarenal gland.

In the experiments of Sugawara ${ }^{24)}$ on cats under urethane or ether, in which the cava pocket was prepared, intravenous nicotine injection in doses of $0.1-0.3 \mathrm{mg}$. per kilo acted to increase the rate of epinephrine discharge from $0.001 \mathrm{mg}$. to $0.005 \mathrm{mg}$. per kilo per minute, roughly speaking, when no neurotomy was done, from $0.00005 \mathrm{mg}$. per kilo per minute to $0.0002-0.001 \mathrm{mg}$. when the splanchnici were cut acutely, and from $0.00005 \mathrm{mg}$. to $0.001-0.002 \mathrm{mg}$. in two cats, the splanchnic nerves of which were cut about ten days previously.

Cutting of the splanchnic nerves for the suprarenal gland under investigation was done acutely on in the experiments of F. Watanab $e^{(0)}$ and of Wada, Hirano and Tiball on dogs, whose suprarenal venous blood was collected in the almost physiological state of animals. The magnitude and course of epinephrine secretion due to uicotine was reduced only a little, or practically unaltered, a large difference compared to the out- 
come in the experiments under quite unnatural conditions; probably noninfluence of excluding the splanchnic innervation upon the accelerated discharge of epinephrine on nicotine intoxication would be elucidated provided a sufficient number of experimentation under normal physiological conditions be carried out after elapsing an enough time after having sectioned the splanchnic nerves.

No difference was also detectable in the glycaemic ability of nicotine in normal dogs and in the acutely doubly splanchnicotomized ones ${ }^{10) 11)}$.

The present data dealt with the paradoxical pupil reaction on nicotine quite harmonize with those dealt with the epinephrine output and glycaemia in relation to their behaviour after excluding the splanchnic nerves.

(3) After double medulli-suprarenalectomy.

Half a month to two months after the last medulli-suprarenalectomy, the drugs were applied.

While a quite small mass of the medullary tissue was found microscopically on post mortem examination in the left gland of M-3, male, the exclusion of medullary mass was complete in all the other glands.

Both tables ( $\mathrm{I} \& \mathrm{II}$ ) reveal a large increase in the i.v. minimum effective dose of both drugs for causing the paradoxical pupil reaction, particularly that of acetylcholine. About four times as large as that for normal cats are required for causing the paradox by acetylcholine, $0.0028 \mathrm{mg}$. per kilo against $0.0007 \mathrm{mg}$. The i.v. minimum effective dose of nicotine was $0.01 \mathrm{mg}$. per kilo for normal cats and $0.015 \mathrm{mg}$. for medulli-suprarenalectomized ones; it is increased by fifty per cent for the latter.

While still occurring of the paradoxical pupil reaction due to $\mathrm{ACh}$ and nicotine after suprarenalectomy has been missed to be found by some previous investigators ${ }^{3)}$ ), the present outcome is clear-cutting, especially for $\mathrm{ACh}$. And while all the investigators thus failed to find the paradox after suprarenalectomy, Dale and $\mathrm{Laidlaw}^{4)}$ came to witness it in cats under urethane or in pitched ones. For the influence of the neurotomy is not so great in the case of nicotine, as shown in the present figures, one should be carefull of the experimental conditions such as narcosis etc.

At that occasion Dale and Laidlaw gave a suggestion of production of a substance with an epinephrine like effect from other sources than suprarenals. They did not take it however as coming from the minor deposits of chromaffine tissue scattered over the sympathetic system, nor with the sympathetic gang- 
lion proper. Ligating the aorta at the diaphragma did not reduce the paradox in their hand to effect to a minimal trace.

What is then responsible for the fact that demedullation of the suprarenals is largely effective in increasing the i.v. minimum effective dose for causing the paradox in the case of ACh, in contrast to that of nicotine?

The paradox occurring on the drugs after double medulli-suprarenalectomy must be taken as due to discharge of an epinephrine like substance from some other" sources than suprarenals, or "sympathin"; then, the i.v. threshold doses for causing its liberation sufficient to bring about the paradox are $0.003 \mathrm{mg}$. per kilo of the cat for $\mathrm{ACh}$ and $0.015 \mathrm{mg}$. per kilo for nicotine.

There is no evidence of acting of the drugs locally on the denervated pupil to dilate. In passing it may be noted: In a cat which always showed the paradoxical pupil reaction on instillation of strong $\mathrm{ACh}$, Shen and $\mathrm{Cannon^{16) }}$ came to miss it after a suprarenal was removed and the fellow demedullated, even when the animal fully recovered.

If the ratio of the threshold dose for normal cats and that for cats with demedullated suprarenals be due to epinephrine liberation from the suprarenals, it must be assumed that the easiness with which epinephrine is liberated respectively on ACh and nicotine and that of "sympathin" do not run parallel, but largely dissimilar.

If we had data relating threshold doses of the drugs for causing hypersecretion of epinephrine from suprarenals in cats under their normal physiological conditions, as in the present experiment, the above question can be readily answered, we suppose. While that of nicotine for the $\mathrm{dog}$ was noted as $0.5 \mathrm{mg}$. for $\mathrm{kilo}^{10}$, that of $\mathrm{ACh}$ is not yet known even for the dog under the conditions above related. And, even if they were known of the dog, they cannot be translated in the term for the eat, as discussed in the start of this paper.

We have some figures rê the amounts of epinephrine output when $\mathrm{ACh}$ and nicotine act to produce it well in dogs under normal physiological state. They are almost similar for both the drugs. On $1 \mathrm{mg}$. per kilo nicotine, i.v., the secretion of epinephrine $0.0001-0.0003 \mathrm{mg}$. per kilo per minute (W a t a n a be $)^{10)}$ or $0.01-0.0007 \mathrm{mg}$. (W ad a ${ }^{11)}$, this time the suprarenal blood was collected from the moment of starting injection), and on $15 \mathrm{mg}$. per kilo $\mathrm{ACh}$, subs., $0.0001 \mathrm{mg}$. epinephrine per kilo p. min. (In a b a) or on 3-5 mg. ACh, i.v., 0.0005$0.0015 \mathrm{mg}$. epinephrine per kilo per min. ( $\mathrm{W} \mathrm{ad} \mathrm{a}^{19)}$; see supra. The figures here cited are taken from their manuscripft which will be published later in this Journal.).

These figures do not seem, however, to afford any contributions towards 
solving the above question in positive sence.

In passing it might be noted that double suprarenalectomy or medullisuprarenalectomy does not materially alter influence of nicotine upon the coagulation time of blood from rabbits. ${ }^{25}$ )

\section{SUMmARY.}

In the cat, the upper cervical sympathetic ganglion of which was removed one to two weeks before, the intravenous minimum effective dose for producing the paradoxical pupil dilatation was measured for acetylcholine and nicotine. Cats were not anesthetised or fastened.

(1) The threshold doses of both drugs were pretty uniform during this period, such as from one week to two weeks after the ganglionectomy. It was approximately $0.0007 \mathrm{mg}$. per kilo for acetylcholine and $0.01 \mathrm{mg}$. per kilo for nicotine. (The drugs were injected not at once, but with a regular interval of discontinuation.) We are here interested of the ratio of doses of both drugs chiefly.

While a similar ratio of both drugs is noted in a previous paper dealt with epinephrine secretion in cats, a rather reverse ratio has been reported in some papers with like kind of researchs with the latter but in $\mathrm{dog} s$.

(2) Double sectioning the splanchnic nerves, carried out two weeks to two months before, lessened distinctly the threshold dose of acetylcholine, but did not alter that of nicotine.

(3) Removal of the suprarenal medulla, done two weeks to two months before, enlarged definitely the threshold dose of acetylcholine and of nicotine, particularly largely the former.

Occurrence of the paradoxical pupil dilatation by the drugs, especially by nicotine, after excluding suprarenal capsules or splanchnic nerves, was that missed by most of previous investigators.

\section{References.}

(1) For references: E. In a ba, Tohoku J. of Exp. Med., 1935, 27, 247; T a neiti, Ibid., 1940, 38, 147. Some papors which were regrettably oversighted in both papers and those appeared subsequently are to be added here for completing the bibliography. $\mathrm{Kur} \in, O \mathrm{kinaka,} O \mathrm{hsh}$ im a, Shimamoto and $O \mathrm{kumura} K \mathrm{~K}$. W., 1986, 15 y., 477; Shima moto, Tokjo Igakkai Zassi, 1938, 52, 26, espacially $61 \mathrm{ff}$. (Dogs, medulla oblongata crushed under local anaesthesia, artificial respiration, ligated all blood vessels of abdominal viscera except suprarenal vessels. Arterial blood pressure recording; appling blood from femoral artery to rabbit ear vessels; applied acetyloholine on suprarenal body itself, +; i.v. atropine annuls the action of ACh. .N.B. In this paper a work of K. Is hi i and H. K ub o, Osaka Igakkai Zassi (Mitt. d. med. Ges. zu Osaka), $1930,29,311$ (English abstract p. 9) is quoted erronously (pp. 61 \& 94), and it almost 
coincides with erronous quotation in Feldberg and Minz, Arch. f. exp. Path. u. Pharm., 1932, 163, 67. Both gave the names of authors, the journal and page as “Is ki i and H. K u bo, Mitt. d. med. Ges. zu Osaka and 31 . Further in text of S. 石丰 (Is hii) is erronously replaced by - 色 (Is shiki, probably somewhat similar to Is $k i$, which sound quite strange as a Japanese name.). And the contents coincide with those of F. \& M., who quoted correctly the description in the conclusion given in the Japanese original and English abstract; but such experiments with $\mathrm{ACh}$, given in both papers, are not involved in the summary in both languages, and in data in the text of $I$, \& $K$., as pointed out in a paper of $E$. In a $\mathrm{ba}^{2}$, which is quoted in $\mathrm{S}^{\prime} \mathrm{s}$ ); Shen and $\mathrm{Can} n$ on, Chin. J. of Physiol., 1936, 10, 368 (A cat, with pupil dilator denervated, ACh instillation oaused paradox; this disappeared after one suprarenal removed and the other demedullated. The authors deem of several mechanisms thereof, one of which is reflex epinephrine discharge.); Wada, Nippon Seiri Z., 1938, 3, 150 ; Jap. J. of Med. Sc., Biophysics, 1938, 5, 142† (Dogs, no narcosis, not fastened, no pain evoking, suprarenal venous blood on rabbit intestino segment, $3-5 \mathrm{mg}$ ACh per kilo, i.. ., hypersecretion of epinephrine due ACh is not reduced by splanchnicotomy.).

(2) For references: Sugaw a ra, Tohoku J. of Exp. Med., 1925, 6, 430, W a da, Ibid., 1935, 25, 14 ; F. Wat a $n$ a be, Ibid, 1935, 27, 335; W a da, Hirano and Tiba, Ibid., 1938, 33, 189. Those publications which were regrettably oversighted in these papers or appeared subsequently are follows: Tainter, J. Pharm. \& Exp. Ther., 1926, 27, 201 (Cats, nicotine is not capable of preventing oedema of paraphenglenediamine provided the suprarenals are removed. A cat, the cava pocket, epinephrine determination by cat intestine \& non-pregnant uterus: About $1 \mathrm{mg}$ nicotine i.v., before no inhibition, max. 17 minutes after $0.00363 \mathrm{mg}$. per kilo per min.; paradoxical pupil, atropin, rabbits nicotine $6.7 \mathrm{mg}$ per kilo per hour, cats $2.8 \mathrm{mg}$. per kilo, fastened, den. pupil dilated; after having removed the suprarenals, no dilatation. While $T$. says that it is confirmative of Shimidz and of $\mathrm{Dale}$ and $\mathrm{L}$ a id law who found that the response of the denervated pupil to nicotine is abolished by suprarenalectomy, the latter authors were able to see the paradoxical pupil dilatation by nicotine, persisting after removal of the suprarenals, in cats under urethane and the pithed ones (p. 22), contrary to the experiments under ether (p. 20).: J. of Physiol., 1912(-13), 45.)

(3) ACh.; Kellaway and C o we11, J. of Physiol., 1923, 57, 87 (A cat, demedullation, $0.04 \mathrm{mg}$ of $\mathrm{ACh}$, no paradox.). Resen blueth, Am. J. of Physiol, 1932, 100, 443 (Cats, dial, after suprarenalectomy, paradox on ACh.). B a cq, C.r. Soc. Biol., 1936, 123, 1021 (Cats, chloralose; dial; nictitating memb., g.c. sup. removed, ACh $1-5 \mathrm{mg}$, contraction; atter evisceration \& removing sympathetic chain, from g.c. sup. to the III sacral, no contraction.) Morison and Acheson, Am. J. of Physiol., 1938, 121, 14 (Cats, dial, stuprarenalectomy, nictitating membrane, paradox on ACh.)

(4) Nicotine: Dale and Laidlaw, J. of Physiol., $1912(-13), 45,20$ \& 22 (Cats, nicotine Under chloroform or ether, no paradox after suprarenalectomy ; weak paradox after splanchnicotomy; under urethane or in pitched cats, weak paradox after suprarenalectomy.). Shimidz u, Arch. f. exp. Path. u. Pharm., 1924, 103, 68 (Rabbits, nicotine, after ligating suprarenals, no paradox.). Ta i n te r, J. of Pharm. \& Exp. Ther., 1926, 27, 201 (Cats, nicotine, after suprarenalectomy no paradox.). Bacq, C.r. Soc. Biol., 1936, 123, 1021 (Details given above for nicotine) nicotine, $0.1-1 \mathrm{mg}$, like with nicotine.).

(5) Sugawara, Tohoku J. of Exp. Med., 1927, 8, 369.

(6) S. Kojima, Tohoku J. of Exp. Med., $1941,40,354$.

(7) Houssay and Moline 11 i, Am. J. of Physiol., 1926, 77, 184.

(8) Feldberg, Minz and Tsudzimura, J. of Physiol,, 1934, 81, 300-301.

(9) E. Inaba, Tohoku J. of Exp. Med., 1935, 27, 245.

(10) F. Watanabe, Ibid., 335.

(11) Wada, Hirano and Tiba, Ibid., 1938, 33, 189.

$142 \dagger$.

(12) W a d a, Nippon Seiri Z., 1938, 3, 150; Jap. J. of Med. Se., Biophysies, 1938, 5, 
(13) Sugrawara, Tohoku J. of Exp. Med., 1925, 6, 444,

(14) E. In a b a, Tohoku J. of Exp. Med., 1935, 27, 245 (Dogs, not anaesthetized, not fastened, epinephrine secretion from suprarenals, blood sugar concentration, after splanchnicotomy hypersensitive to $\mathrm{ACh}$, especially after that done two months before.):

(15) Brown, Dale and Feld berg, J. of Physiol, 1936, 87, 394 (Cats, a dog, m. gastrocunemius, 10-18 days after section of the sciatic nerve, spinal preparation, hypersensitive to $\mathrm{ACh}$.).

(16) Shen and Cann on, Chin. J. of Physiol., 1936, 10, 359 (Cats, excision of a ciliary ganglion or section of the short ciliary nerves, pupillary sphineter hypersensitive to $\mathrm{ACh}$, the maximum within $24 \mathrm{hrs}$. after excision.).

(17) Pierce and Gregersen, Am. J. of Physiol., 1937, 120, 246 (Dogs, submaxillary gland, 6 days or later after section of the chorda tympani \& chorda lingual nerves, less secretion on $\mathrm{ACh}$.).

(18) Wada, Nippon Seiri Z., 1938, 3, 150 ; Jap. J. of Med. Sc., Biophysics, 1938, $5,142+$ (Dogs, experimental conditions like to I $a^{2} b^{14}$ ). 3-5 mg ACh per kilo i, v, hypersecretion of epinephrine due $\mathrm{ACh}$ is not altered materially by acute splanchnicotomy.).

(19) Simeone, Cannon and Rosenblueth, Am. J. of Physiol., 1938, 122, 94 (Cats, upper cervical ganglion, partially denervated 3-6 weeks before, dial, hypersensitive to nervous impnlse reaching it through the remaining preganglionic fibres.).

(20) S i m e on e, Am. J. of Physiol., 1938, 122, 186 (Cats, suprarenal gland, partly denervated 3-6 weeks before, under dial the paradoxical pupil reaction, hypersensitive to electric stimulation of the remaining nerves for the gland.).

(21) Morison and Aches on, Cit, in Simeone (18) (They (unpublished observations) "tested the responses of denervated and normal adrenal glands to injeetions of acetylcholine, but the results were not decisive ".).

(22) Sime one and Maes, Am. J. of Physiol., 1938, 123, 189 (Proc.) (Cats, upper cervical ganglion extirpated 47-90 days before; under urethane, chorda cut, suprarenals removed, saliva from submaxillary gland, response to $\mathrm{ACh}$, in 3 out of 10 , denervated gland showed definitely greater response than the control, in 4 slightly greater and in 3 no difference.).

(23) Maes, Am. J. of Physiol., 1938, 123, 359 (Cats, upper cervical ganglion removed 11 days or further before, nembutal, lachrymal secretion, hypersensitive to $\mathrm{ACh}$, i.v., regardless whether suprarenals are remaining intact or one gland removed and the other demedullated. If acutely ganglionectomized, no hypersensitiveness takes place.).

(24) Sugawara, Tohoku J. of Exp. Med., 1925, 6, 430.

(25) S. Kan o woka, Tohoku J. of Exp. Med., 1934, 24, 307. 